British Journal of Education

Vol.8, Issue 3, pp.27-40, March 2020

Published by ECRTD- UK

Print ISSN: ISSN 2054-6351

Online ISSN: ISSN 2054-636X

\title{
THE CURRICULUM ROLE IN THE DEVELOPMENT OF STUDENTS THINKING IN EDUCATION FACULTY AT HAIL UNIVERSITY TO ACHIEVE THE REQUIREMENTS OF INTELLECTUAL SECURITY (ONE COURSE MODEL)
}

\author{
Dr. Wafa Mahmoud Mohammed Ayasrah \\ Assistant Professor - Faculty of Education - Hail University \\ wwafaa1980@gmail.com
}

\begin{abstract}
The research aims to show The curriculum role in the development of students thinking in Education Faculty at Hail University to achieve the requirements of intellectual security, the research uses the descriptive curriculum to its suitability to achieve its objectives, as it means by describing reality and explaining it and trying to develop solutions to suit its development, by showing the concept of intellectual security And how to achieve its requirements, and the role of the university curriculum in the development of students' thinking and development to achieve the requirements of intellectual security, by analyzing (social upbringing) course in child kindergarten department, and show its role in achieving these requirements, the most significant result appears that the course play big role in the development of thought emerging and enhancing intellectual security if it is applied practically in real life.
\end{abstract}

KEYWORDS: role, curriculum, intellectual security.

\section{INTRODUCTION}

Intellectual security is one of the most important aspects of national security, because it is concerned with preserving the self and identity, the integrity of thought and mind is one of the five necessities that Islam emphasized to be saved and preserved, which includes mind, religion, wealth, self and offspring. People can only be as straight as life in its necessary aspects, and the security disturbance is only the result of breaching its preservation, so preventive intervention by educational institutions is required to teach Muslim youth what is required from them in this era to build effective and highly motivated generation (Hussein, 2012).

Sultan (2009) emphasized that intellectual security fights every extreme thought and protects the human being from deviation or deviation from moderation in his understanding of various issues. The University is one of the most important educational institutions that should play a leading role in achieving intellectual security, as its field of work extends to every family in society and is entrusted with the education that concerns everyone, and prepares the teacher to play this role. The University is responsible for building the personality of individuals and refining them in accordance with social and ethical values by developing well-thought-out plans and programs to achieve intellectual security in the minds of students within the vocabulary of the curriculum, 
British Journal of Education

Vol.8, Issue 3, pp.27-40, March 2020

Published by ECRTD- UK

Print ISSN: ISSN 2054-6351

Online ISSN: ISSN 2054-636X

which is carefully selected so as to achieve the principle of authenticity and modernity together, In addition to his heritage and cultural values (Al-Mel hem, 2009).

Anani (2013) confirms that the university stage is one of the most important educational stages that is concerned with preserving security and stability and achieving the intellectual security to the students of and whole society, so if this stage is directed the right way, it arises a sound genesis that protects society from extreme intellectual diseases may destroy it. The university curriculum is an important part of education, and it is the essence of the educational process, because of its values, principles, experiences, skills, science and knowledge, which are the basis for building and developing the student's personality in an integrated development from all sides. Therefore, fortifying the youth thought from deviant ideas and currents is the solid basis from which all aspects of educational activities in educational and social institutions are launched to prevent the nation and constitution from any Violation that targeted its institutions or social and religious Constant directions (AL Junahy, 2000).

University courses are one of the most important elements on which the university educational process depends on, and it should include scientific and practical content, in addition to educational experiences that play a major role in shaping the personality of the university student, and contribute significantly in reducing intellectual deviation.Therefore, curriculum must be a modern and adjustable by the time and keep pace with all its developments, this era is the era of globalization and disappearance of borders between the countries all around the world, which make it important to subject our educational curriculum to open review to accommodate the nature of this era and its variables and surprises (Hussam al-Din, 1999).

\section{The Study problem:}

In light of the political, social and cultural changes taking place in the world in general and Arab societies in particular, the strengthening of intellectual security and its requirements has become an urgent necessity in light of cultural pollution, religious excesses and weak political awareness that has spread among the youth of the Muslim community.

Educational institution has a strategic role in preparing and developing youth, so it has become necessary for university education to include concepts of intellectual security to address the intellectual deviations that confront students as updated challenges. The curriculum is an institutional social work, and its contents and methods of design and implementation are essentially one of the most important policies of society, so it is necessary to review the curriculum that suffers from poor content. Therefore, this study came to demonstrate the role of the curriculum in the development of students ways of thinking, the Faculty of Education at Hail University in achieving the requirements of intellectual security and its role in confronting those challenges, and an attempt to prove that the courses taught by the Faculty of Education in the branch of children kindergartens play a major role in the upbringing of young people and raise them awareness of the requirements of security intellectual and practice it in the ground. 
British Journal of Education

Vol.8, Issue 3, pp.27-40, March 2020

Published by ECRTD- UK

Print ISSN: ISSN 2054-6351

Online ISSN: ISSN 2054-636X

\section{The Study questions:}

1. What is the concept of intellectual security and the requirements for achieving it?

2. What is the role of university curricula in achieving intellectual security requirements?

3. How can the curricula in the Faculty of Education in children kindergarten branch meet the requirements of intellectual security?

\section{The Study objectives:}

1. To indicate what is meant by the concept of intellectual security and the requirements for achieving it.

2. To reveal the importance of university curricula in achieving intellectual security requirements. 3. Determine how the university curricula in the Faculty of Education in the children kindergarten branch can meet the requirements of intellectual security.

\section{The Study importance:}

1. The importance of the study comes from the importance of the topic you are dealing with, which is the subject of intellectual security and the requirements for achieving it.

2. The importance of the study also comes from the fact that it draws the attention of stakeholders towards some of the shortcomings and shortcomings of some courses in the face of the requirements of the times.

3. Contribute to the statement of the requirements for achieving intellectual security and educating students in it.

\section{Terminology and procedural definitions:}

- Role: The behavior expected of the individual and others from him, these expectations are influenced by the understanding of the individual and others of the rights and duties associated with his or her social status, and the limits of the role include those acts accepted by society in the light of the levels of behavior in culture (Awahd, 2017).

The role in this study means the actual functions and objectives, as well as the expected, which must be carried out by some curricula in order to meet the intellectual security requirements of students of the Faculty of Education at The University of Hail.

- Curriculum: The total educational experiences that the university prepares for students inside or outside it with the intention of helping them to achieve comprehensive growth in all mental, cultural, social, physical and technical aspects, which leads to a modification of their behavior, and works to achieve the desired educational goals.

- Intellectual security: joint interaction, measures and activity between the State and society to work to avoid members of the State and groups ideological, intellectual or psychological defects that cause the behavior of individuals' ideas and morals to deviate from social values and ideals in society (Al-Rayai, 2009).

In this study intellectual security means to fortify the university as an educational institution for the minds of its students by educating them and instilling the right values and beliefs they have with the aim of directing their behavior in a way that achieves community security and stability in all aspects of life. 
British Journal of Education

Vol.8, Issue 3, pp.27-40, March 2020

Published by ECRTD- UK

Print ISSN: ISSN 2054-6351

Online ISSN: ISSN 2054-636X

The researcher uses the descriptive approach to its suitability to achieve the study objectives, as it means describing reality and interpreting it and trying to develop solutions to suit its development, and research here seeks to demonstrate the role of the curriculum in the development of the thinking of students of the Faculty of Education at The University of Hail in achieving the requirements of intellectual security.

\section{Study limitations}

The generalization of this study is subjected to the following:

1. This study analyzed one basic book curriculum (social upbringing), for the academic year (2019-2020).

2. This study restricted by Faculty of Education - Kindergarten Department - Hail University, for the academic year (2019-2020).

3. Previous studies:

-The Study of Al-Borai (2000) which aimed to identify the roles that university can play through its various courses, activities and programs, inside and outside the university borders, to overcome intellectual extremism and violence among some of the university's youth in Egypt, the historical curriculum was used to record the facts and events that affected Egyptian society during the last quarter of the twentieth century, as the descriptive curriculum was used to monitoring, describing and analyzing the concepts used in the study, then analyzing the determinants of the educational and service role of the university, then reviewing Intellectual facts upon the age phase of university students, as well as he use the survey as a method of social survey on sample of students of some Egyptian universities, to identify their opinions towards two issues (intellectual extremism, violence), the study most important results: the economic changes in Egypt during the last quarter of the twentieth century and the legacy of Social, financial and cultural disadvantages, as well as unemployment and the lack of educational and educational services in the university, as well as the prevalence of negatives in society, such as corruption, bribes and embezzlement, as well as the media's shortcomings towards strengthening positive values, are the reasons that cause intellectual extremism and violence on some young people in Egypt.

- The Awed Study (2018): Aimed to identify the role of the university curriculum in addressing intellectual extremism from the point of view of faculty members at Kuwait University, the study adopted the descriptive analytical approach, the study found that there are no statistically significant differences in the faculty's estimates of the role of the curriculum University in the treatment of intellectual extremism due to the variables of academic rank, experience and gender, the study recommended to reconsider the delivered values to address intellectual extremism in the university curriculum in a way that achieves greater continuity.

- Study of Tashkindi (2016) which aimed to identify the role of the educational curriculum and teachers in enhancing the intellectual security in the students and the obstacles face them in performing their role, the study adopted the descriptive analytical curriculum, and the results showed that the teachers' estimates of the role of the curriculum and teachers in promoting intellectual security were average. 
British Journal of Education

Vol.8, Issue 3, pp.27-40, March 2020

Published by ECRTD- UK

Print ISSN: ISSN 2054-6351

Online ISSN: ISSN 2054-636X

- Al-Houshan Study (2015): Aimed at identifying a clear concept of intellectual security and knowing the responsibility of the school curriculum and teachers in addressing intellectual extremism from the teachers point of view, the researcher adopted the descriptive analytical curriculum, the results did not show any statistically significant differences in the degree of teachers' appreciation of the role of the curriculum in their School in addressing intellectual extremism due to verbal's of qualifications and experience.

- Shaldan Study (2013), The study aimed to identify the role of faculties of education in enhancing the intellectual structure of their students and ways to activate it, he used the analytical description curriculum, and he found that there are no statistically significant differences between the averages of responses due to the verbal's in the level of study, the study recommended to activate the role of educational colleges in Palestinian universities to enhance intellectual security.

- The Study of Mohammed (2013), Aimed to identify the role of the university in achieving the concept of intellectual security among university students and the most important requirements of achieving intellectual security, the study reached the importance of helping students and motivating them with the requirements of intellectual security through the development of the preparations and abilities of students to meet the challenges that Facing their society, promoting behaviors that lead students to keep pace with civilization, and coming up with a contemporary national Islamic thought that preserves the constants and believes in development, teaching them some concepts related to the issue of intellectual security, which is a component of the university education courses as the most important stages. The researcher has extrapolated some of the courses of some colleges in the Saudi Arabia Kingdom where he did not find an interest in intellectual security or in the concepts associated with it, which in turn reflects on students.

- The study of Ashareefain(2015), Aimed at identifying the concept of intellectual security, the content of the educational curriculum and showing its importance to the individual and society, and showing the criteria for selecting the educational curriculum that achieves intellectual security, the study used the descriptive analytical curriculum and inductive approach curriculum .The study concluded that the most important foundations of building intellectual security are the religious intellectual and social foundations, as proposed a strategy for the role of educational content in achieving intellectual security, he recommended that the principles of intellectual security should be included in the educational curriculum.

\section{THEORETICAL FRAMEWORK}

Security is a great blessing that people feel only when they are lost, reasonable thinking is main in security pillars, If thought deviates from the straight middle approach to extremism or intellectual deviations, security disrupts society and at that time there are many conflicts, disputes and parties that weaken the nation and makes it accessible by enemies (Al-Turki, 2010). 
British Journal of Education

Vol.8, Issue 3, pp.27-40, March 2020

Published by ECRTD- UK

Print ISSN: ISSN 2054-6351

Online ISSN: ISSN 2054-636X

\section{The concept of intellectual security:}

The term intellectual security is a modern and contemporary term, so the language dictionaries did not include a specific definition of it, a complex term that combines two important aspects of the lives of individuals and societies, namely security and thought. The word security means reassurance of the soul and the disappearance of fear, and it sometimes makes safety a name for the situation in which a person is in security, and sometimes a name for what a person believes in (Al-Isfahani, 1992).Security may mean "the stability, security and tranquility felt by the individual and society, and within which the nation can devote itself to building and developing in various fields of life" (Shamas, 2003).There are those who means by security, is a sense of safety and reassurance, the disappearance of the causes of fear for human life, and the interests that this life seeks to achieve and uses in achieving its aspirations (Rashid, 1988).

Thought means: (mental activity sentence): it may mean the mental image of something (Arabic language complex).

Thought may mean: the works of the mind in the known to reach the knowledge of the unknown (Al-Ayed, 1988)

The meaning is that the normal person is required to act with the right thought to build in the various affairs of his individual and community life, Good thought is the supreme mental and human activity, just as deviations and harmful activities to people's interests and the purposes of Shari'a ,always stand behind it a sick, poisoned and adulterated thought (Al-Jonahi, 2000).Based on the different meanings and definitions above, it is possible to come out of the whole term intellectual security as: the integrity of thought from deviations and deviation from moderation and moderation in understanding religious, political and social matters, leading to the preservation of public order and stability ( Al-Hothaili, 2011). It is also intended to protect the ideology and beliefs of society from being attacked or harmed (Shaldan, 2013).

\section{The importance and objectives of intellectual security}

Islam forbids the intellectual deviation of extremism as one of the most important and serious threats to intellectual security, and there are many sources in Islamic legislation( Ayat and hadiths) that forbid extremism in all of it images. The importance of intellectual security can be explained according to the following points:

- Intellectual security is the true gateway to the creativity and growth of the civilization and culture of society.

- Intellectual security search how to confront crime in general and violence in particular.

- It is a protection for the most important gains and the greatest necessities.

- It is a guarantee of the independence and excellence of nations (Call, 2004).

Therefore, there is a need for intellectual security that addresses every alien thought and protects the human being from deviation or deviation from moderation in his understanding of various issues, and aims to achieve security, stability and tranquility in the aspects of life, and for people to live safe on their originality and culture. 
British Journal of Education

Vol.8, Issue 3, pp.27-40, March 2020

Published by ECRTD- UK

Print ISSN: ISSN 2054-6351

Online ISSN: ISSN 2054-636X

Intellectual security objectives (Abu Arad, 2010):

- Rooting human values and principles that promote loyalty and belonging.

- Educating young people on the right thinking that can distinguish between right and wrong.

- Gaining young people the right thoughts and the ability to exchange ideas with others.

- Establishing a sense of responsibility towards the country security and maintaining it.

- Emphasizing the concept of moderate thought that distinguished the Islamic thought.

- Achieving coexistence of individuals in peace and security, which has a positive impact on the stability and preservation of society.

- Promoting a spirit of love and cooperation between individuals and keeping them away from division and difference.

\section{Reasons for achieving intellectual security:}

1. Following The Guidance of God: By sticking with the Book of God and the Sunnah of his Prophet, this is the true security that leads to the security of thought.

2. To glorify and stand by the Islamic texts: this is the method of the righteous salaf and by them the Shaba, the satisfaction of Allah, that they do not exceed ten verses until they work with them . 3. The validity of understanding of texts: This reason is a fundamental pillar of the validity of inference, and many intellectual deviations are due to misunderstandings and the authenticity of the understanding of texts is only achieved by relying on scientific origins (AL-Soyin,1422)

4. Seeking useful knowledge: One of the most important aspects of intellectual security and the means of achieving it is to provide the teaching of faith sciences that guide the path of guidance that the Holy Qur'an has brought, and call for mature intellectual awareness and following the right path.

5. Good work: Good worship has major implications for the life of the Muslim, including peace of mind, reassurance and a sense of security (Al-Hadhili, 2013)

\section{Stages for achieving intellectual security:}

There is no doubt that intellectual security is an important and precious demand, as it achieves many things, and shortens many efforts and the most important stages are:

Stage 1: Prevention of intellectual deviation: through primary and secondary social upbringing institutions and other institutions in accordance with well-thought-out plans setting goals and objectives (Al-Dosari, 2012).

Stage 2: Discussion and Dialogue: Prevention efforts may not succeed in repelling deviant ideas from reaching some individuals, whether the source of these ideas internally or externally, which creates some of these ideas to some extent in parts of society, It will then spread and attract more followers, which calls for the intervention from thought and opinion leaders, scholars, intellectuals and researchers to address these ideas through face-to-face meetings with their followers, using evidence-backed statement of truth and argument to persuade them (Al-Shahrani, 2010).

Stage 3: Validation phase: begins with validating the deviant thought and assessing its seriousness as an inevitable result of dialogue and discussion, and then moves on to another level of evaluating and correcting this thought as much as possible by persuasion and evidence (Al-Elwaehg, 2005). 
British Journal of Education

Vol.8, Issue 3, pp.27-40, March 2020

Published by ECRTD- UK

Print ISSN: ISSN 2054-6351

Online ISSN: ISSN 2054-636X

Stage 4: Accountability and Punishment: this stage is directed at those who did not respond to the previous stages, and be confronted with the intellectuals deviant they hold, which is carried out by official bodies of the state and the judiciary system which is responsible for issuing the legitimate judgment against those who hold such thought to protect society from the dangers that may cause. (AL-Saadi, 2005).

Stage 5: Treatment and rehabilitation: intensive dialogue with intellectually deviant persons, and this is done through scientifically and intellectually qualified in various disciplines, especially scientists who are qualified to counter the suspicion of the argument (Al-Maliki, 2007).

\section{The university's role in achieving intellectual security requirements:}

Educational institutions are the main source which students acquire knowledge, develop their skills and develop their behaviors. The University represents the pinnacle of the educational system in our contemporary reality, and the ultimate educational end for students in various fields of science and knowledge (Shaldan, 2013).Abdul Mohsen (2009) emphasizes that the university stage represents the highest awareness, understanding for students as they are provided with preventive doses, that take into account the impact on the student's sense and social affiliation, which prompts him to adhere to the systems and instructions in all his behaviors. Universities should attention to strengthening the affiliation of these young people to their society, and their association with their basic goals and issues through the active movement of the energies of young people, the most important of which is the moral energies that are represented by religious and cultural values that are reflected in the behavior of individuals and groups and in their dealings with each other.

Based on the university's role as an educational and intellectual institution created by the community to develop and discuss its problems, Ali identified the most important principles that the university must follow to meet intellectual and cultural challenges(Ali, 2007):

- Maintaining the authentic Islamic ideology that prevails in society and defending its existence, and identity by confronting studies, criticism and analysis of the intellectual currents in which it is coming and highlighting its deficiencies or errors.

- Ensure that conferences and seminars are held which discuss aspects of intellectual security, clarify the intellectual deviations of students and warn against falling into them.

- Highlighting the role of faith and adhering to the principles of Islam, including fulfilling the homeland and maintaining its security.

- Warning against suspicious media sources, and publications issued by unofficial sources and not participating in their publication

Educational institutions can play their role in achieving intellectual security by:

- Educational institutions continue the process of socialization in order to shape the student's personality and ensure that he or she is familiar with what is around him.

- Introducing the student to his social functions, and ensuring that education is a human social function before it is informative.

- Expanding the scope of dealing and human relations and interaction with different community groups. 
British Journal of Education

Vol.8, Issue 3, pp.27-40, March 2020

Published by ECRTD- UK

Print ISSN: ISSN 2054-6351

Online ISSN: ISSN 2054-636X

- Linking students to the culture prevailing in society, introducing them to the heritage of their nation and instilling a spirit of renewal and creativity.

- Linking educational activities to community efforts (Faraj, 2005).

The role of the university curriculum in achieving the requirements of intellectual security: Curriculum is one of the most important elements on which the university educational process depends, and includes scientific and practical content, and educational experiences that are provided to students, whether inside or outside the classroom, through which the objectives of the educational process can be translated into educational situations can be translated into educational situations measured and straightened.

The importance of curriculum role in protecting them from intellectual deviation is clear as reflecting the relevant educational objectives in the face of misleading calls ,so the following should be considered:

1. The decisions should be based on the correct Islamic faith and linking the general concepts to believing in God and worshipping him.

2. University courses should contain cognitive, emotional and skills objectives to immunize students from intellectual deviations and make them aware of the risks that face them.

3. Courses should include activities aimed at immunizing the ideas of students from deviation.

4. To make students aware of the importance of preserving the Islamic identity, and its high values and meanings and ideals of the human orientation, whatever its religion, gender or color.

5. Courses should include higher thinking skills, from analysis, thinking and criticism to make the student being able to criticize and explain the events, situations and developments that occur.

6. To focus on concepts that show the importance of the role of the university student in building the future of his nation and maintaining the stability of the society in which he lives.

7. Courses should contribute to the development of students' abilities and skills and employ them properly, to occupy their time to their benefit (AL-Zahrani, 2018).

A model of the curriculum taught in the Faculty of Education in the Department of Kindergartens at Hail University and its role in achieving the requirements of intellectual security:

Kindergarten specialization is one of the most specialized disciplines aimed at raising and educating children, qualifying and empowering teachers capable of raising the child and qualifying him appropriately in educational and scientific ways through careful, deliberate and elaborate steps to include the child's behavioral, mental, social and psychological aspects.

The child is in its early stages as a seed, if its best germination will bear fruit, and the task of the kindergarten specialist is to create a suitable environment for the child to know the outside world away from home, to deal with a large world without fear by providing them with knowledge and skills that will help them to achieve this.

The role of the "social upbringing" course in the development of students' thinking to achieve the requirements of intellectual security: 
British Journal of Education

Vol.8, Issue 3, pp.27-40, March 2020

Published by ECRTD- UK

Print ISSN: ISSN 2054-6351

Online ISSN: ISSN 2054-636X

Social upbringing is one of the most dangerous processes in the life of the individual, because it plays an essential role in the formation of the social personality of the individual, and be aware and responsive to social influences with all the pressures that these influences impose on him through social upbringing processes and The child - but also the adult - also changes, and the social effects he is subjected to as he enters a new social group or institution, and whenever he enters into a social role that is unfamiliar to him and requires him to modify his or her behavior or gain new behavior.

This course contains several topics:

1. The concept of social upbringing : concern for social systems that will transform a person - that organic material - into a social individual capable of interacting and integrating easily with members of society, a process through which children acquire the moral and self-control necessary for them to become adults members Responsible in their community; socialization according to the social concept is only to train individuals in their future roles to be active members of society, and to teach them social values, customs, traditions and custom prevailing in society to achieve harmony between individuals and standards Social laws, leading to the creation of a solidarity and cohesion in society.

The process of learning, teaching and education, based on social interaction and aims to give the individual (child and adolescent, bedding and elderly) appropriate behavior, standards and attitudes to certain social roles, enabling him to keep up with his group and social harmony with it, gain him social character, and make it easier for him to integrate into Social life.

2. Factors that help social upbringing: individual factors: inheritance, biological potential, learning ability, flexibility and empathy.

Society Factors include: social position and roles, the values and norms prevailing in the society in which they live, and social institutions.

3. Social upbringing institutions: family, educational institutions, media, sports institutions, religious institutions, and the various and varied institutions of social upbringing which work together to form the personality of the individual and achieve an integrated social development of the individual.

4. Parental attitudes and their impact on the child's psychological life: these are the procedures that parents follow in raising their children, i.e. converting them from mere biological beings to social beings, and psychological trends in parental treatment methods of children: the trend of bullying, the trend of protection excess, the direction of neglect, the direction of pampering, the direction of psychological pain, the trend of cruelty, the direction of oscillation, the direction of differentiation, and the direction of both.

5. The needs of the child and the role of social upbringing in satisfying them are: the needs of physical, mental and emotional development and the most important consequences of not satisfying needs is frustration that contributes to the creation of an abnormal personality suffering from frustration for their needs or conflict between these needs, and the incompatibility with their selves or with others who live in the society around them. 
British Journal of Education

Vol.8, Issue 3, pp.27-40, March 2020

Published by ECRTD- UK

Print ISSN: ISSN 2054-6351

Online ISSN: ISSN 2054-636X

Through the above, appears the great impact that the social upbringing course has on the formation of the student's personality and its development in all respects to achieve the requirements of intellectual security by focusing on the satisfaction of the basic needs for them, properly through the study of personality and its components, characteristics and association Social upbringing methods and the impact on balanced growth and on the formation of the personality of the individual and his ability to interact, adapt and agree with both himself and other people surrounding him, so the focus should be on the causes and obstacles of not satisfying the student's basic needs, which lead later to deviation.

The experiences that the child goes through in the early stages have a great impact on his behavior later, if he is not given attention and love, it leads to a compulsive tendency that lasts with him for life and pushes him towards achieving what is forbidden, or gaining what he lost in his early childhood and this happens in a symbolic or realistic way; Basic needs can lead to aggressive attitudes towards the whole world or to certain types or topics such as political, religious or intellectual extremism.

As a result of the tremendous and rapid developments in Arab and Muslim societies, there is an urgent need to give students positive thinking skills and this is achieved through the acquisition of different thinking skills, whether basic thinking skills or higher thinking skills according to their abilities. Their different levels of maturity help him overcome many deviant ideas because they raise the level of his thinking and opinions, through which intellectual security can be enhanced. To achieve the requirements of positive thinking as one of the dimensions of intellectual security by training students in dialogue and literature and accepting others different opinions and warning against intolerance of opinion to a particular doctrine or thought, and developing critical thinking skills and training them to think and draw from different texts, and training on Be careful not to rush in judgment before verifying their safety, and the courses include activities and training to develop higher thinking skills.

\section{MOST SIGNIFICANT RESULTS}

1. rise up the concept of intellectual security and its importance, objectives, reasons and stages of its achieving.

2. Highlighted the importance of the role of universities in immunizing students from intellectual deviation.

3. The study stressed on the importance of the curriculum in universities in immunizing students against intellectual deviation and educating them against misleading attacks against them.

\section{Recommendations}

To achieve the requirements of intellectual security and protect society from intellectual deviations:

1. We should focus on the need to satisfy the basic needs of the human being properly, and to look for reasons and obstacles for not satisfying them that lead to deviation. 
British Journal of Education

Vol.8, Issue 3, pp.27-40, March 2020

Published by ECRTD- UK

Print ISSN: ISSN 2054-6351

Online ISSN: ISSN 2054-636X

2. Achieving intellectual security among young people is one of the most important means of achieving a secure and stable society, the more aware, understanding and awareness the more it belongs to its country and is more concerned with its security and stability.

3. Focus on protecting the mind and protecting it from going out of the middle bath.

4. The focus should be on social institutions in instilling the concept of security in general, and intellectual security, especially because the student acquires knowledge and grows his skills and develops his behaviors and attitude negatively or positively according to the directions of the institution, so these institutions must cooperate with each other to achieve the system Security.

5. The vocabulary of the curriculum is carefully selected so that it achieves the principle of authenticity and modernity together.

6. Educating the individual on the positive thinking that is able to distinguish between right and wrong and useful from the harmful.

7. Develop university courses to include activities aimed to protect the ideas of female students from deviation, taking into account the diversity and activities to suit the wishes and inclinations of the students and ensure their participation in them.

8. Focus on positive thinking skills, development and achievement of their requirements, and this is achieved by having different thinking skills according to their abilities and levels of maturity.

9. Holding courses and programs to promot intellectual security behaviors and their positive effects among members of society.

10. Holding awareness programs aimed to spread the values of intellectual security among members of society, representing them in mind, emotion and behavior.

\section{References}

- Abdul Mohsen, Bania bint Fahd al-Malham (2009): Universities and the intellectual security industry, research and presentation of the first National Conference on Intellectual Security Concepts and Challenges, Naif Bin Abdul Aziz Chair for Intellectual Security Studies, King Saud University, from 22-25 May 1430 Ah- 2002.

- Abu Arad, Saleh (2010): The role of the University in achieving intellectual security, a proposed conception, the Arab Journal of Security Studies and Training, MJ (27), P (52), The Arab University of Saudi Arabia's Nayef University of Sciences.

- Ali, Said Ismail (2007): Culture of Educational Reform, World of Books, Cairo.

- Anani, Hanan (2013): Educational Psychology Dar al-Fikr, Amman

- Ashareefain, Matalqa, Masada, (2015). Promoting Intellectual Security in the content of educational Curricula: A theoretical study, Journal of Scientific Research, The Research and studies, Center at king Fahd college, (2460,123-157) prince Naïf university for security societies, forested edition

- Hadhili, Said Suleiman (2013): Requirements for improving intellectual security through educational curricula, conference on the phenomenon of atonement: causes- effectstherapy, book of the eighth axis, Imam Mohammed Bin Saud Islamic University, Medina, p. $4569-4619$ 
British Journal of Education

Vol.8, Issue 3, pp.27-40, March 2020

Published by ECRTD- UK

Print ISSN: ISSN 2054-6351

Online ISSN: ISSN 2054-636X

- Awahd, Amal Jaber (2017): A proposed vision of the role of the community specialist to enhance the intellectual security of university youth, the Journal of Social Service, the Egyptian Society of Social Workers, Egypt.

- Awed, Noura Mohammed (2018): The role of the university curriculum in addressing intellectual extremism from the point of view of faculty members at Kuwait University, Journal of Educational and Social Sciences, Kuwait University, MJ (5), P (14)

- Ayed, Ahmed, et al. (1988): Basic Arabic Dictionary, Arab Organization for Education, Culture and Science, La Rose, Tunisia

- Call, Carolyn MARY (2004). Intellectual safety: and Epistemological position in the college classroom.PH.D. Dissertation, United States, NEWYORK, Camel University.

- Hussein, Mohammed Fathi (2012): A proposal to activate the role of Tabuk University in enhancing the intellectual security of students, the Journal of Arab Studies in Education and Psychology, c (2), p (25).

- Shamas, Salem Bin Mostahil (2003): Studies in Psychology and Mental Health - Contemporary Vision, Modern University Book House, Shabin Al-Kum.

- Al-Borai, Wafa Mohammed (2000): The university's role in countering intellectual extremism and violence among young university students in Egyptian society, unpublished Ph.D., Faculty of Education, Alexandria University

- Al-Dosari, Mohammed Abdullah (2012): Preventive methods of intellectual deviation in middle and secondary students, $\mathrm{PhD}$ thesis, Um al-Qura University.

- Al-eLaehg, Abdul Rahman (2005): Intellectual Security and Its Controls, Center for Studies and Research, Nayef Arab University for Security Sciences, Riyadh

- Al-Janahi, Ali Fayez (2000): A Vision of Intellectual Security and Ways to Counter Deviant Ideology, Nayef Arab University for Security Sciences, Arab Journal of Security Studies and Training, $\mathrm{p}(27)$

- Al-Junahy, On (2000): Security Media and Crime Prevention, Nayef Arab Academy of Security Sciences, Center for Studies and Research, Issue No. (254), Riyadh.

- Al-Hothaili, Majid (2011): The concept of intellectual security is a rooting study in the light of Islam, Master's Thesis, Faculty of Sharia, Imam Mohammed Bin Saud Islamic University, Saudi Arabia.

- Al-Houshan, Baraka (2015): Defining a clear concept of intellectual security and knowing the responsibility of school curricula and teachers in addressing intellectual extremism from the point of view of teachers, Police Thought Magazine, Police Research Center, Sharjah, UAE, MJ (24), P (94).

-AL- Isfahani, Ragheb (1992): Vocabulary of the Words of the Qur'an, By Safwan Adnan Daoudi, Dar al-Qalam, Damascus

- Al-Melhem, Benneh (2009): University and intellectual security industry psychological reading of university relations with intellectual security in Saudi society, First National Conference on Intellectual Security Concepts and Challenges, King Saud University.

- Al-Maliki, Abdul Hafeez (2007): Building a national strategy for achieving intellectual development in the face of terrorism, Ph.D., Nayef Arab University of Sciences, Saudi Arabia 
British Journal of Education

Vol.8, Issue 3, pp.27-40, March 2020

Published by ECRTD- UK

Print ISSN: ISSN 2054-6351

Online ISSN: ISSN 2054-636X

- Mohammed, Abdel Nasser Radhi (2013): The role of the university in activating the intellectual and educational security of its students, educational magazine, faculty of education, University of Sohag (33).

- Al-Rayai, Mohammed Abdul Aziz (2009): The role of the curriculum in promoting the concepts of intellectual security among university students in Saudi Arabia, the first National Conference on Intellectual Security under the theme (Concepts and Challenges), Prince Nayef Bin AbdulAziz Chair for Intellectual Security Studies, King Saud University

- Faraj, Abdul Latif Hassan (2005): The high school principal's mission of the attitude of deviant behavior among young people from the point of view of high school principals, community and security seminar, King Fahd Security College, Riyadh.

- Rashid, On (1988): University and University Teaching, Al Shorouk Publishing, Distribution and Printing House, Jeddah.

- Saadi, Amna (2005): Intellectual Security: Concept, Parameters and How to Investigate, Meeting and Coordination of Directors of Research and Criminal Justice Centers on Intellectual Security, Nayef Arab University for Security Sciences, Medina.

- Shahrani, Bandar Ali (2010): A proposal to activate the role of the secondary school in achieving intellectual security, Master's thesis, Um al-Qura University

- Shaldan, Fayez (2013): The role of educational colleges in Palestinian universities in enhancing the intellectual security of their students and ways to activate it, The Journal of the Islamic University for Educational and Psychological Studies, MJ (21), P (1), Gaza, Palestine.

- Soyin, Ahmad (1422): The method of receiving and inferring between the Sunnis and the creator, the Islamic Forum, i (3).

- Tashkindi, Leila (2016): The role of educational curricula and teachers in enhancing intellectual security in students and the obstacles they face in performing their role, teacher preparation conference in light of the demands of development and the new times of the times, Um alQura University, Saudi Arabia

- Turki, Youssef Abdullah (2010): Some love to my son, i (1), The Obeikan Library.

- Zahrani, Majid (2018): The role of Saudi universities in immunizing students against intellectual deviation - a proposed vision, a conference of duty saudi universities and their impact on protecting young people from groups, parties and delinquency, organized by Imam Mohammed Bin Saud Islamic University 11-12 May 1439, 28-29 January, MJ (6), p (2241). 